\title{
Kas iskelet sistemi hastalıklarında kök hücre uygulamaları
}

\section{Stem cell applications in musculoskeletal system diseases}

\author{
Işık Akgün
}

Gayrettepe Florance Nightingale Hastanesi, İstanbul

\begin{abstract}
Son yıllarda ortopedide, özellikle kıkırdak lezyonlarında, erişkin kök hücre uygulamaları kullanılmaktadır. Rejeneratif tıp, artık her konuda güncelliğini arttırmaktadır. Ülkemizde de 2009 yılından itibaren kullanımı başlamış ve günümüze kadar değişen teknolojiler ile uygulamaları artmıştır. Rejeneratif tedaviler için biyolojik ürün hazırlamada başlıca iki yöntem vardır: kök hücre, GMP laboratuvarlarında kültür şeklinde elde edilip uygulanabildiği gibi, kemik iliği ve yağ dokusundan tek seans olarak elde edilerek de kullanılmaktadır. Ortopedik işlemler için, lokal kıkırdak lezyonlarında esas olarak açık cerrahi ile membranlı kök hücre uygulaması, dejenere eklem sorunları için ise rejeneratif hücre kokteyli enjeksiyonları tercih edilir.
\end{abstract}

Anahtar sözcükler: erişkin kök hücresi; kök hücre; rejeneratif tıp; kıkırdak lezyonları
Recently, the adult stem cell treatment has gained a great interest for cartilage lesions. Indeed, regenerative medicine has a growing implication in almost every medical specialty. First clinical application in our country has been realized in 2009, and with the new technologies in this field, treatments have increased since then. There are mainly two methods for the preparation of these biological products for regenerative treatments: obtaining cultured products by amplification of cells in GMP laboratories, or preparing regenerative cell concentrates directly from bone morrow and fat tissues which lets us use the product in a single procedure. For the orthopedic procedures mainly the scaffolds embedded with stem cell are constructed in local cartilage lesions with open surgery techniques, whereas intraarticular regenerative cell cocktail injections are preferred for degenerated joint problems.

Key words: adult stem cell; stem cell; regenerative medicine; cartilage lesions

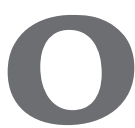

rtopedik cerrahlar için kıkırdak lezyonları tedavisi zor olgulardır. Son yıllara kadar orjinal hiyalin kıkırdak dokusunu oluşturacak bir tedavi şekli bulunamamış olmakla birlikte, birçok teknik uygulanmıştır. Ancak, biyolojik tedavi yöntemlerinin güncellenmesi ve hücre tabanlı tedavilerin gündeme gelmesi ile, kıkırdak lezyonları tedavisinde ciddi yol alınmıştır. 1994 yılından itibaren, önceleri kondrosit hücre ve beraberinde periost, daha sonra da skafold uygulamaları başlamıştır. Son yıllarda ise, erişkin mezenkimal kök hücrelerinin avantajları sayesinde bu hücrelerin kullanımı başlamıştır.

\section{KÖK HÜCRE NEDIR VE ÖZELLiKLERi NELERDiR}

Yetişkinlerdeki hücre ve dokuların yenilenmesi ve onarımı yetişkin kök hücreleri ile sağlanır; bazı dokular için de bu yenilenme ve onarım süresi kesintisiz ve oldukça hızlı gerçekleşir. Bu yenilenme ve onarım, o dokunun hücrelerinden köken alarak gerçekleşir. Bütün bu olayları yapan hücreler, organizmada üç tiptir;

1- Kök hücreler.

2- Farklılaşmanın çeşitli aşamalarında bulunan somatik hücreler.

3- Germ hücreleri.

Kök hücreler bir yandan kendi yedeğini yaparken, diğer yandan da yenilenecek dokunun gereksinimi olan ve farklılaşma yönünde ilerleyecek olan hücreye dönüşür.

Son yıllarda onarımsal tıptaki yerlerinin giderek artmasıyla birlikte, embriyo dışı dokular olan plasenta, amniyon zarı ve göbek kordonundan elde edilen kök hücreler çok önem kazanmıştır. Bu hücrelere "fetüs kök hücreleri" de denmektedir. Bunlar, embriyo kök hücreleri ile yetişkin kaynaklı kök hücreler arasında çoğalma ve farklılaşma yeteneklerine sahiptir. Bir diğer

- İletişim adresi: Prof. Dr. Işık Akgün, Florance Nightingale Hastanesi, Gayrettepe, İstanbul

Tel: 0533 - 7601206 e-posta: drisikakgun@gmail.com

- Geliș tarihi: 20 Mart 2017 Kabul tarihi: 20 Mart 2017 
ortak özellikleri de gebelik sırasında fetüse zarar vermeden veya doğum esnasında kolaylıkla alınabilir olmalarıdır. ${ }^{[1,2]}$

Kök hücre tanımını yapmak için birkaç temel ölçüte ihtiyaç vardır. Bunlar kök hücrenin tanımını oluşturur:

1- Kendini yenileme özelliği.

2- Farklı hücrelere dönüşme yeteneği.

3- Klon oluşturma yeteneği. ${ }^{[3,4]}$

Organizmanın oluşum başlangıcında çok önemli olan embriyo kök hücreleri, çok kısa ömürlüdür ve hızla embriyo gövdesini oluşturan katmanlara farklılaşır. Bu nedenle, bu hücreler ancak deneysel amaçla kullanılmaktadır. İnsanlarda kullanımı ise oldukça sınırlıdır.

"Yetişkin kök hücreler" ise organizmada yaşam boyu süre gelen yenilenme ve doku onarımı gibi yaşamsal olaylardan sorumlu olan hücrelerdir.

Bizi en çok ilgilendiren, kök hücre özelliklerinden biri olan "farklılaşma yeteneği" dir.

Eğer tek bir hücreye farklılaşan bir kök hücre ise, buna unipotent hücre denir ve "öncü hücre" ya da "progenitör hücre" adı verilir. Bu hücreler, kök hücreden köken almış olup çoğunlukla bir veya iki farklı hücreye dönüşebilen ve sınırlı sayıda çoğalan hücrelerdir.

Bu hücreler farklılaşma özelliklerini doğal çevrelerinden aldıkları sinyaller ile yapmakta ve başka bir hücreye farklılaşmaktadır. ${ }^{[5]}$

Kök hücrelerinin bir diğer özelliği de klon oluşturması, yani, tek bir hücreden çok sayıda yeni kök hücre oluşturmasıdır.

Bu özellikleri sayesinde, hücreler kültüre edilebilir ve aynı tipten çok fazla koloni şeklinde üretilebilir. Böyle oluşturulan kök hücrelerin de kendi başına çoğalması ve klon oluşturmasını sağlamak gerekir. Bunun için de, telomeraz enzim etkinliğini yükseltmek gereklidir. Böylece, sınırlı sayıda çoğalabilen ve erken yaşlanan hücrelerin, daha uzun süre ve yaşlanmadan kültürünü yapmak ve saklamak mümkündür.

Şu anda, Ortopedi ve Travmatoloji ve diğer branşlarda kullanılan kök hücre tipi, mezenkimal kök hücredir. Birden fazla hücre serisine farklılaşabilmeleri (multipotensi) ve in vitro çoğalabilmeleri nedeniyle, bu hücreler "mezenkimal kök hücre" (MKH) olarak adlandırılır. ${ }^{[6]}$

Bu hücreler mezoderm dokusunun öncü hücreleri olduğu için, bağ ve destek dokularının (kemik, kıkırdak, kas), yağ dokusunun ve vasküler sistemin temel hücrelerine dönüşür; işte bu özelliklerinden dolayı, ortopedide özellikle kıkırdak lezyonlarının onarımında kullanılmaktadır. ${ }^{[7,8]}$

MKH kaynaklarının başında, insan vücudunun özellikle damardan zengin bağ dokusu içeren dokuları gelmektedir. ${ }^{[8]}$ Bunlar arasında; kemik iliği, yağ dokusu, sinoviyum ve göbek kordonu stroması sayılabilir. ${ }^{[9]}$

Bu hücre kaynaklarını değerlendirirken, kişinin yaşını da dikkate almak gereklidir. MKH sayısı yaşla birlikte azalır. Yenidoğanın kemik iliğinde her 10.000 çekirdekli hücreden biri MKH iken, erginlik yıllarında bu sayı 100.000 'de bir, 30 yaşında 250.000 'de bir, 50 'li yaşlarda 400.000'de bir ve 80'li yaşlarda 2.000.000'da bire düşmektedir. ${ }^{[10]}$

MKH hücrelerinin kültüre edilmesinde de önemli bir olay, kültür pasaj sayısının çok fazla olmamasıdır. Yani, çok sayıda hücre elde etmek için daha fazla pasaj yararlı olmamaktadır. Illeri pasajlarda, hücrelerde genetik bozukluklar oluşmakta, yaşlanma artmakta ve farklılaşma yeteneği azalmaktadır. ${ }^{[11]}$

Klinikte kullanacağımı MKH kültürlerinin mutlaka GMP (Good Manufacturing Practices - İyi Üretim Uygulamaları) standartlarında olması gerekir. Sağlık Bakanlığı da bu konuda kök hücre uygulama tüzüklerini oluşturmakta ve denetlemektedir. ${ }^{[12]}$

Kordon kanı kaynaklı MKH, kemik iliğine alternatif hale gelir. Ancak, Caplan tarafindan yapılan çalışmalarda, kök hücrelerin kordon kanında olmadığı ve bunların kordon stromasından geldiği gösterilmiştir; kordon stroması bu yüzden çok önemlidir. ${ }^{[13]}$

Klinik olarak, "kordon kök hücreleri" kıkırdak lezyonlarında kullanılır. İmmün baskılayıcı özellikleri nedeni ile, osteoartritte ve romatoid artritte de kullanılmaya başlanmıştır. ${ }^{[14]}$ Kök hücrelerinin en önemli özelliklerinden biri olan immün sistem modülatörü olması, kendisine antijenik etki oluşmasını engeller ve bu sayede otoimmün hastalıklarda kullanımı önem kazanır.

Bugünkü görüşler çerçevesinde, yağ dokusundan elde edilen $\mathrm{MKH}$ çok daha fazla kullanılır hale gelmiştir. MKH'nin hem elde edilmesi daha kolaydır hem de daha fazla kök hücre içerir. Son zamanlarda kıkırdak cerrahisinde de kullanımı artmıştır; "adipoz kökenli kök hücreler” olarak isimlendirilmiştir. Tipik MKH özelliği taşıyan bu hücreler, plastiğe yapışarak çoğalır ve multipotent farklılaşma yeteneğine sahiptir. ${ }^{[15]}$

Kök hücre kullanımı, kemik hastalıkları ve dolayısı ile kemik dokusunun onarımında, bugünkü tıpta önemli bir yer tutmaktadır. Burada, kök hücrelerinin osteojenik farklılaşmaları çok önemli rol oynar. Dünya Sağlık Örgütü, 2000-2010 yıllarını 'Kemik ve Eklem On Yılı' olarak duyurmuştur.

Kök hücrelerinin asıl kullanımı, kemik hastalıkları yanı sıra, kondrojenik farklılaşmalarının çok iyi olması nedeni ile kıkırdak lezyonlarında olmaktadır. ${ }^{[16,17]}$ Özellikle, kıkırdağın kendini yenilemesinin olmaması veya çok sınırlı olması nedeni ile kök hücre çok ön 
plana çıkmıştır. Hiyalin kıkırdağın çevresinde perikondrium bölgesindeki kondroblastların bir miktar yenilemeye katkısı vardır, ancak kıkırdak lezyonlarının çoğu perikondriuma kadar uzanamamaktadır. Büyük lezyonlar da fibröz kıkırdak dokusu ile iyileşir. Bu lezyonlar ilk olarak 1994'te, kondrosit hücrelerinin kullanımı ile tedavi edilmeye başlanmıştır.

Ancak, kondrositlerin elde edilme zorluğu, sayıca az olmaları ve yaşama şanslarının az olması, büyük sorun oluşturmaktadır. Bu yüzden, MKH uygulamaları kıkırdak lezyon tedavisinde ümit verici hale gelmiştir.

ilk defa 1998 yılında Johstone ve arkadaşları, in vitro ortamda MKH'nin kıkırdak dönüşümünü göstermişlerdir. ${ }^{[17]}$

In vitro kondrojenik farklılaşmada iki temel yöntem vardır:

1- Sıkı bir 'hücre-hücre' ilişkisinin sağlanması.

2- Askorbik asit ve büyüme hormon faktörlerinin biyolojik etkinliği olan kondrojenik maddelerin konması. ${ }^{[18]}$ Bunların en etkilileri, deksametazon, askorbik asit ve TGF- $\beta$ 'dır.

MKH'ler, kondrojenik farklılaşma sırasında fibroblast benzeri görünümlerinden küresel biçime dönüşür. Hücreler, kollajen Tip 2'nin oluşturduğu ağsı ve bol miktarda matriks ile çevrelenir. ${ }^{[19]}$ Eğer kültür yapıllyorsa ve ortama askorbik asit koyarsanız, hücrelerin çoğalmasını arttıııken Tip 2 kollajen sentezini de uyarırsınız. Diğer kondrojenik maddeler de kollajen sentezini uyarır.

MKH'nin yaşlanması ve tümöre dönüşmesi de en çok konuşulan özelliklerdir. Yaşlanma kriteri, telomeraz enziminin azalması ve etkinliğinin düşmesidir; kısalan telomer boyu ve $\mathrm{P} 16$ yükselmesi, MKH'nin ömrünün azaldığını gösterir. Yaşlanan hücre hacimce büyür, sitoplazmada yağ vakuolleri birikir, mitoz durur ve hücre apopitoza girer. ${ }^{[20]}$

Uzun süre kültüre edilen ve yaşlanmayan hücrelerin tümöre değişiminin olup olmadığını anlamak için sitojenik analizler ve PCR (Polymerase Chain Reaction) analizi yapılır. Son yapılan çalışmalarda, doku mühendisliği veya immün baskılama amacı ile in vitro ortamda çoğaltılan klinik kalitedeki MKH'nin tümöre dönüşüme yatkın olmadığı gösterilmiştir. ${ }^{[21]}$

Kısaca, kromozom anomalisi çıksa da çıkmasa da, MKH giderek azalan mitoz etkinliği gösterir ve belirli sayıda bölünmeden sonra, gerek in vitro gerekse in vivo koşullarda yaşlanmaya girer.

MKH'nin nasıl iyileştirmeye etkili olduğu, yapılan birçok in vitro çalışmada gösterilmiş ve sonuçta klinik olarak kıkırdak lezyonları tamirinde kullanılmaya başlanmıştır.
Hatta, MHK'nin sistemik olarak da verilerek hedef bölgeye yönelmesi ve oraya tutunması, hücresel tedavinin de olacağını göstermiştir. Çeşitli hastalıklarda, örneğin osteogenezis imperfektada, klinik düzelme tespit edilmiş olup MHK'nin bu etkileri sadece farklılaşma ile değil bazı enzimleri salgılayarak oluşturduğu söylenmektedir. Fibrozis oluşumlarında $\mathrm{MKH}$ sistemik verildiğinde, fibrozisi azaltmaktadır ve bu, bazı antifibrotik maddeler salgıladığını göstermektedir. ${ }^{[22,23]}$

Daha önce bahsettiğimiz immün sistem düzenleyici etkilerini de, salgıladığı sitokin ve kemokin etkisiyle yapar.

MKH'nin doku homeostazı üzerine de etkileri vardır.

MKH'ler lokal veya sistemik uygulandığında, üzerlerindeki yapışma molekülleri ile lezyonlu bölgeye yapışır. Özellikle VCAM-1 (vascular cell adhesion molecule 1), fibronektine bağlanmayı sağlar. ${ }^{[24]}$

Ayrıca, kültüre edilmiş hücrelerin göç edebilmelerini sağlayan bir programlarının olduğu düşünülmektedir. Mekanizma tam açıklanamasa da, bunu matriks metalloproteanaz moleküllerinin etkisi ile yaptığı bilinmektedir. ${ }^{[25]}$

Bu hücrelerin en önemli etkilerinden olan immün sistem düzenlemesini, immün sistem tarafından tanınmaması ve immün yanıtlarını engellemesi ile yapar. ${ }^{[26]}$ Kemik iliği ve yağ dokusundan elde edilen hücreler üzerinde çalışmalar yapılmış ve $M K H^{\prime}$ 'erin allojenik nakillerde kullanılabileceği gösterilmiştir; yani, "red" cevabı alınmamaktadır ve farklı organlar içinde (örneğin, karaciğer) kullanılabilir.

MKH hücreleri bu etkilerini, zayıf immünojeniteye sahip olmakla, dendritik hücrelerin işlevlerini arttırarak ve T hücre çoğalmasını baskılayarak yapar. ${ }^{[27-29]}$

MKH'lerin kullanımları henüz yeni olmakla birlikte, lokal lezyonların onarımında organizmaya verilmeden önce laboratuvarlarda istenen hücre tipi in vitro olarak farklılaştırılabileceği gibi, daha yaygın olarak 1-3 pasajlarda yeterli hücre sayısına ulaşıldığında farklılaştırmadan da vücuda verilir. Hücrelerin lezyonlu bölgeyi bulup oraya yerleşme yeteneği sayesinde, lokal uygulama dişında parenteral uygulama da yapılabilir.

Bugün yapılan tüm klinik çalışmalar, MKH'nin dört temel özelliğine dayanarak oluşturulmaktadır:

1- Osteokondrojenik farklılaşma kabiliyeti.

2- Kemik iliğinde kök hücreleri destekleme yeteneği.

3- İmmün baskılayıcı olmaları.

4- Trofik etkiler. 


\section{KIKIRDAK LEZYONLARININ KÖK HÜCRE ILE TEDAVISi}

Kıkırdak dokusunda az hücre olması damarlanma ve sinir sisteminin olmaması, lezyonların iyileşmesini zorlaştırmakta, hatta onarım hiç olmamaktadır.

Eklemleri çevreleyen hiyalin kıkırdak, yaş ilerledikçe ve yüklenmeler arttıkça bozulmakta ve dejenere olmaktadır. Söylediğimiz gibi hiç onarılma ihtimali olmadığından, yaş ilerledikçe ciddi klinik sorunlar çıkar. Günümüze kadar bu amaçla çok çeşitli tedavi yöntemleri geliştirilmiş̧tir; hiyalin kıkırdak oluşumu sağlanamamış lezyonlar ancak fibröz kıkırdak ile iyileşmektedir ve bu dokunun ömrü uzun olmamaktadır. Tedavide amaç, hiyalin kıkırdağı oluşturmaktır. MKH'nin kullanımı da bunu sağlamak içindir.

Buradaki en önemli sorun, özellikle subkondral kemiğe kadar ilerlememiş parsiyel lezyonlarda, verilen kök hücrelerin, yeterli hasar yanıtının verilememesi nedeni ile lezyon bölgesine ulaşamamasıdır. Subkondral lezyon varsa, bölgesel sitokinlerin salgılanması bu etkinliği arttırır. Ancak yine de, kök hücrelernden oluşan kondrositlerin oluşturduğu kıkırdak dokusu çoğunlukla fibröz kıkırdak karekterindedir. İleri çalışmalarda, gen uygulaması ve büyüme faktörlerinin $\mathrm{MKH}$ ile birlikte kullanılmasıyla, hiyalin kıkırdak oluşumu sağlanmıştır.

Kıkırdak lezyonlarında kullanılacak MKH kaynaklarından en önemlileri, kemik iliği ve sinoviyum olmakla birlikte, son zamanlarda yağ dokusu çok ön plana çıkmış; hem alımının kolay olması, hem de miktar olarak çok bulunması ve içinde tuttuğu MKH hücre sayısının daha fazla olması avantaj sağlamıştır.

MKH, kültür edilerek kullanıldığı gibi farklı teknolojilerle kültür edilmeden de kullanılmaktadır. Çeşitli ülkelerde bununla ilgili teknik ve cihazlar geliş̧irilmiştir. Hücreleri ayırmak, gerek enzim kullanarak gerekse de hiç enzim kullanmadan mekanik yollarla mümkündür. Burada elde edilen hücreler \%100 MKH olmamakla birlikte, \%1-4 oranında MKH ihtiva eder. Bu tip elde etmelerde enzim kullanıldığında, minimal manipülatif uygulamadan söz edilmektedir. Bu enzimlerin oluşturulması ve cihazların pahalılığı, yöntemin yaygın kullanımını engellemektedir. Hiç enzim kullanmadan elde edilen hücre süspansiyonları, hem daha ucuzdur hem de daha kısa sürede elde edilir. Bu teknikler, hastaya tek seansta ve ameliyathanede uygulanır. Kültürde olduğu gibi beklemek ve ikinci bir girişim söz konusu değildir.

MKH'nin kullanımı, Türkiye de ilk olarak 2009 yılında oluşturulan proje çerçevesinde, Cerahpaşa Tıp Fakültesi Ortopedi ve Travmatoloji kliniğinde gerçekleştirilmiştir.

$\mathrm{MKH}$, lokal kıkırdak lezyonu olan genç hastalara ve orta yaşta dejeneratif kıkırdak lezyonu olanlara kullanılmıştır. Fokal lezyonlarda skafold şeklinde, dejeneratif lezyonlarda ise intra-artiküler enjeksiyon tarzında uygulama yapılmıştır.

Tüm hastalara, ilk girişimde artroskopik teknik ile lezyonlar tanımlandıktan sonra, kemik iliği ponksiyonu veya sinoviyal biyopsi yapılmış ve materyaller GMP kriterlerine sahip laboratuvara gönderilmiştir. Yaklaşık 3-4 hafta içinde, MKH bu örneklerden izole edilip kültür yapılmıştır.

Lokal lezyonlar için kültüre edilen MKH'ler membran üzerine ekilmiş, dejenere olgular ise enjeksiyon şeklinde uygulama yapmak üzere flokan şeklinde kliniğimize gönderilmiş ve hastalara bu hücreler uygulanmıştır. Takipleri 3-6-12 ay ve izleyen yıllarda yapılmıştır. Takiplerde; klinik değerlendirme, radyolojik değerlendirme ve skorlama sistemleri kullanılmıştır.

Yirmi yedi hastanın 33 eklemine MKH uygulanmıştır; yaşları 18-60 arasındadır. İki grup hasta oluşturulmuştur:

- Grup 1 lokal tam kat $2 \mathrm{~cm}^{2}$ den büyük lezyonu olan hastalardı (diz, kalça ve ayak bileği eklemleri). Bu hastaların hepsinde eklem stabilitesi tamdı, dizilim bozukluğu yoktu ve dizlerde menisküs dokusunun \%50'sinden fazlası korunmaktaydı.

- Grup 2 ise orta derecede osteoartritik dejenerasyonu, diz ve ayak bileği lezyonları olan hastalardı.

Hastaların kültürlerindeki hücre sayısı, lezyonların büyüklügüne göre santimetre kareye 3-5 milyon gelecek şekilde hesaplandı.

Kültürlerin kalite kontrolleri kapsamında; hücre sayısı, canlılık oranı, sterilite, endotoksin seviyesi, tümörojenite değerlendirmeleri ve doku analizleri yer almaktaydı. Özellikle CD 34, 45, 90, 73 ve 105 marker analizleri yapıldı.

Skafoldlu kök hücre uygulanacak hastalarımızda, mini-artrotomi ile lezyon yeri nekrotik dokulardan temizlendikten sonra lezyonun şablonu çıkarılır ve aynı şekil ve boyutlarda skafold hazırlanarak lezyon üzerine uygulanır (Şekil 1). Burada dikkat edilecek husus, ilk bilgilerimize göre subkondral kemiği tam korumak ve kanatmamak olmakla beraber, uygulanan kök hücrelerin aktif hale gelmesi için bir uyarının olması gerçeğidir ve bu nedenle, artık subkondral kemikte mikro-delikler açmaktayız.

Skafold tespitinde, dikiş ile birlikte sadece etrafa fibrin yapıştırıı kullanılmaktadır.

Enjeksiyon uygulanacak hastalarda bu işlem, normal intra-artiküler enjeksiyon uygulama kriterlerine göre yapılmıştır. 

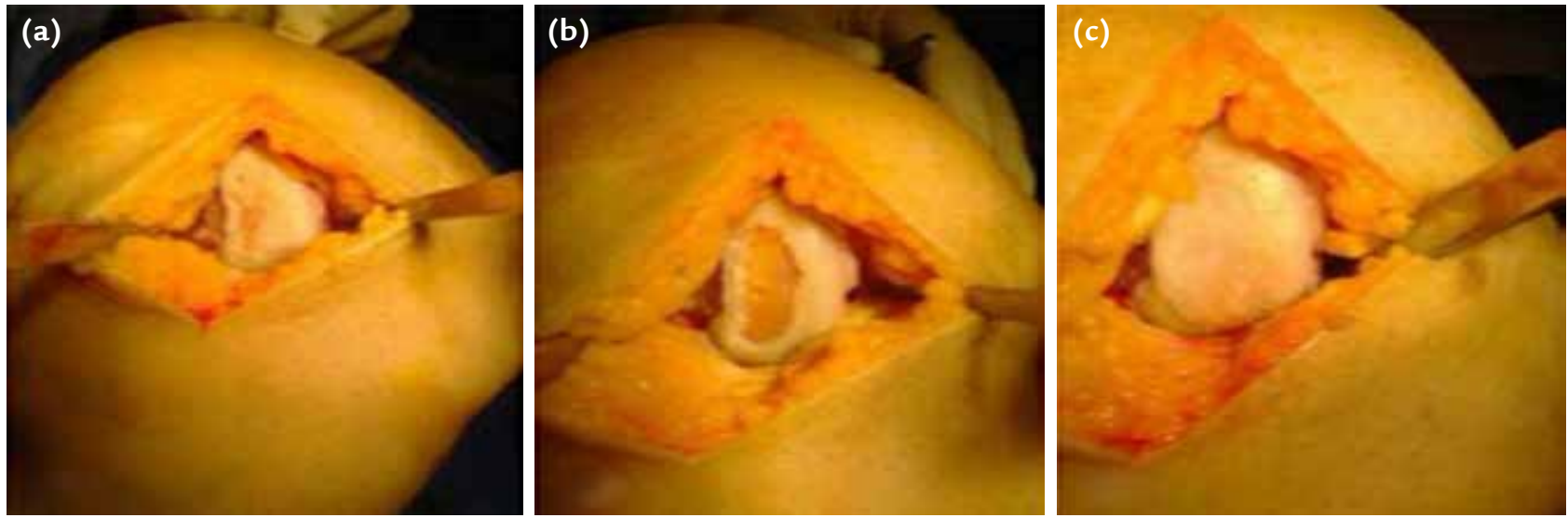

Şekil 1. a-c. Mediyal femoral kondildeki kıkırdak lezyonuna kök hücre implantasyonu: lezyon (a); debridmandan sonra lezyonun görüntüsü (b); otolog kök hücreler implante edilmiş membranın implantasyonu (c).

Uygulama sonrası hasta rehabilitasyonunda, enjeksiyon yapılanlarda hemen ağırlık vermeye ve normal günlük yaşantılarına dönmeye izin verilmiştir. Skafold uygulananlarda ise, yük verme yönünden başlangıçta altı hafta basma yasağı vermemize karşılık, artık 10-15 gün basma yasağının yeterli olduğunu düşünmekteyiz. Eklem mobilizasyonu, normal izometrik egzersizlerle birlikte hemen yapılmaktadır.

Hastalarımızın, önceleri 3, 6 ve 12 aylık daha sonra yılda bir olmak üzere, ortalama dört yıl takipleri yapılmıştır.

Takiplerde, klinik değerlendirme ile birlikte manyetik rezonans (MR) görüntüleme yapılmaktadır. Bir yıl sonunda T2 mapping MR görüntüleme de yapılır (Şekil 2). Klinik değerlendirmede, IKDC (International Knee Documentation Committe), VAS (Visual Analogue Scale), diz için Lysolm skorlama, ayak bileği için AOFAS (American Orthopaedic Food and Ankle Society) skorlama ve kalça için de HOS (Hip Outcome Score) sistemi kullanılmıştır.

Sonuçların değerlendirilmesinde, birinci grupta ameliyat öncesi değerlendirmeye göre ciddi iyileşme saptandı ve daha sonraki yıllık değerlendirmelerde hastaların bu iyileşmeyi sürdürdükleri tespit edildi.

İkinci grup hastalarımızda bir yıl sonunda \%85 düzelme görülürken, son kontrollerde bu oran $\% 75$ olarak saptandı.

Hastalarımızın ancak üçüne, bir yıl sonra ikinci kontrol artroskopisi yapıldı. Gözlemsel ve prob muayenesinde, lezyonun tamamen kapandığı ve orta sertlikte kıkırdak dokusunun oluştuğu; sağlam kıkırdak ile uyumu devamlılığı ve eklem geometrisinin çok iyi olduğu görüldü.
MR değerlendirmede, özellikle bir yıldan sonraki T2 mapping'lerde, Grup 1 hastalarda implantasyon yerinde normal veya normale yakın görüntü yanında defektin \%75'inin dolduğu görüldü.

İkinci grup hastalarımızda ise, kıkırdak yüzeylerinde ciddi bir değişim saptanamamış olmasına rağmen, subkondral ödemde kaybolma ve kıkırdak fissürlerinde düzelme görüldü. Defekt sahasında yeni kıkırdak formasyonu saptanamadı ama osteoartritte ilerleme olmadı.

\section{TARTIŞMA}

Tüm çalışmalar, kondrosit hücre uygulamalarının yeterli doku ve yeterli matriks oluşturmadığını; etkili tamir etme cevabının da yeterli olmadığını göstermiştir. ${ }^{[30,31]}$ Çünkü bu uygulamaların proliferatif kapasitesi düşüktür; ayrıca, hücreler enkapsüle kalmaktadır ve ekstrasellüler matriks migrasyonu da yoktur. Kondral defekte implante edilen kondrosit hücrelerinin transferi, penetrasyonu ve yeni bir kondral birim yaratması yoktur. ${ }^{[32,33]}$ Kondrositlerin klinik uygulamasında, subkondral kemik sağlam bırakıldığı için kemik iliğini kullanamaz; eğer subkondral kemiği debride ederseniz, bu sefer de iyileşmeyi inhibe eder. Kondrosit uygulamada istenen, subkondral kemiğin sağlamlığı veya onarılması olmalıdır. Fakat, histomorfolojik olarak bakıldığında ve kıkırdaktan biyopsi yapıldığında, implante edilen kondrosit hücrelerinin subkondral kemik reaksiyonunu provoke ettiği, fakat lezyonun strüktürel tamirine direkt olarak etki etmediği gösterilmiştir. ${ }^{[31,34-42]}$

Erişkin mezenkimal kök hücreler pluripotenttir ve kondrositten daha fazla proliferasyon kapasitesine 

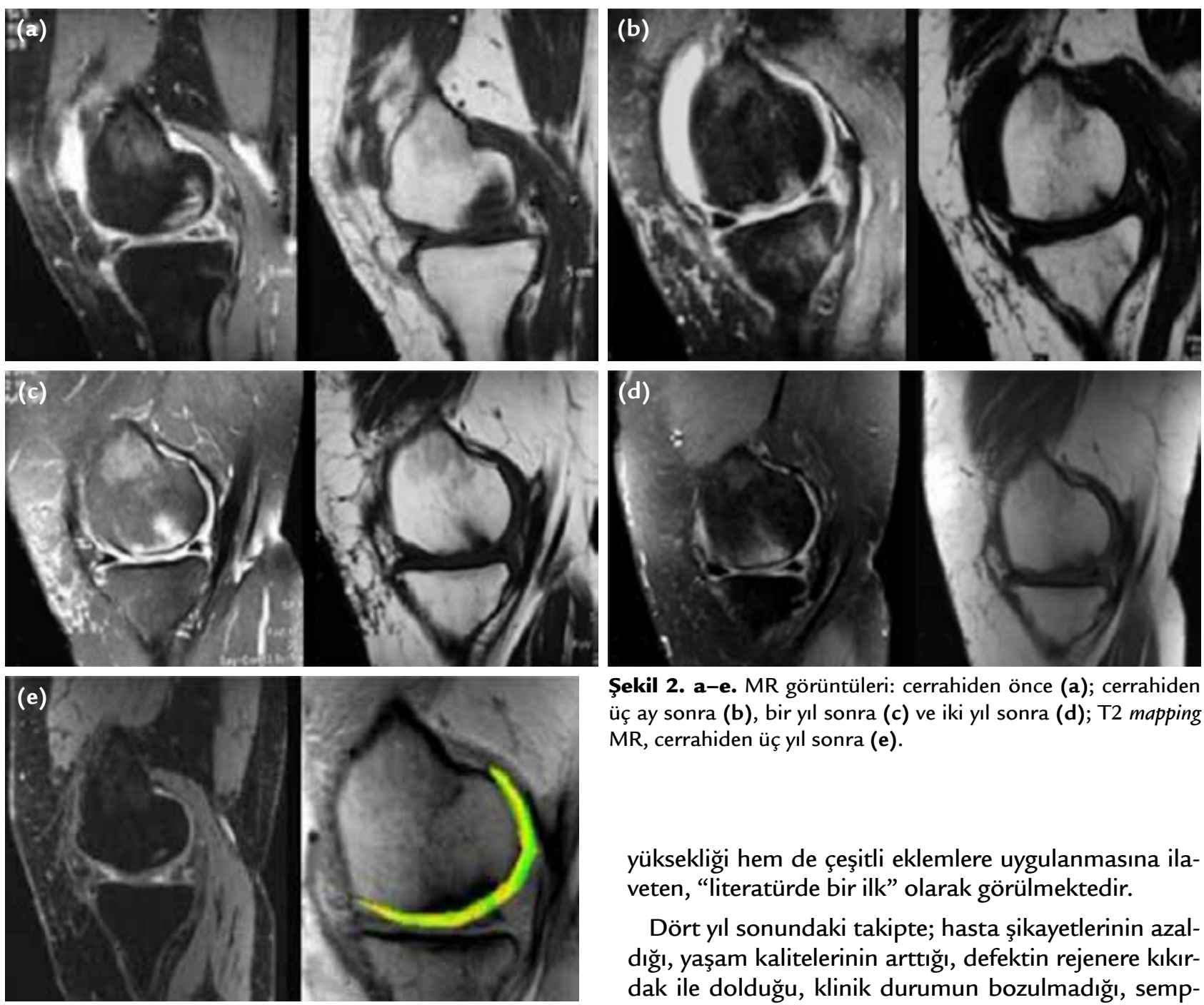

Şekil 2. a-e. MR görüntüleri: cerrahiden önce (a); cerrahiden üç ay sonra (b), bir yıl sonra (c) ve iki yıl sonra (d); T2 mapping $\mathrm{MR}$, cerrahiden üç yıl sonra (e).

sahiptir; ayrıca, trofik etkileri de doku mühendisliğinde çok önemli rol oynar. Birçok çalışma, MKH'lerin normal eklem kıkırdağı veya matür hiyalin benzeri doku yarattığını göstermiş̧tir. ${ }^{[43]}$

MKH implantasyonu, kondrosit uygulaması yapılan tüm endikasyonlarda kullanılabilir. Ayrıca, kondrosit hücrelerine karşı da avantajları vardır. Bunlardan bir tanesi, doku formasyonunun diğer tekniklerle oluşan dokudan çok daha fazla hiyalin kıkırdağa benzemesidir. ${ }^{[39]}$ Diğer avantajı ise, elde edilmesinin kemik iliğinden ve yağdan çok daha kolay olmasıdır. Ayrıca, MKH trofik etkileri ile immün sistemi modüle ederek suprese eder ve allojenik olarak kullanılmalarını da sağlar. ${ }^{[44]}$

Çok az sayıda MKH uygulamalı klinik çalışma vardır. ${ }^{[45-47]}$ Bizim çalışmamız ise, hem hasta sayısının

yüksekliği hem de çeşitli eklemlere uygulanmasına ilaveten, "literatürde bir ilk" olarak görülmektedir.

Dört yıl sonundaki takipte; hasta şikayetlerinin azaldığı, yaşam kalitelerinin arttığı, defektin rejenere kıkırdak ile dolduğu, klinik durumun bozulmadığı, semptomların tekrarlamadığı ve uygulanan implantın oluşturduğu dokunun kaybolmadığı gösterilmiştir. Tüm bunlara rağmen, orijinal hiyalin kıkırdak formasyonu ideal olarak elde edilmemiştir. Bunun için daha fazla çalışma gereklidir.

Osteoartritli hastalarda enjeksiyon şeklinde MKH uygulamasında ise, bu hücrelerin tropik etkileri immüno-regülatör ve anti-inflamatuvar fonksiyonları ile görülmektedir. Bu etkilerinden dolayı, sadece osteoartrit olgularında değil inflamatuvar hastalıklara bağlı kıkırdak lezyonlarında da kullanılmaktadır.

Yağ dokusundan MKH elde edilmesinin daha kolay olması ve bu dokunun daha fazla kök hücre içermesi nedeni ile, yağ dokusu kullanımı daha fazla popüler olmaya başlamıştır. Ayrıca, yağ dokusundan kültür yapmaksızın kök hücre konsantrasyonu elde etmek her zaman mümkündür (Lipogems ${ }^{\circledR}$ tekniği). Elde edilen materyal \%100 kök hücre değildir ama içinde \%1-5 oranında kök hücre bulundurur ki bu da milyonlar sayısına yakındır. 

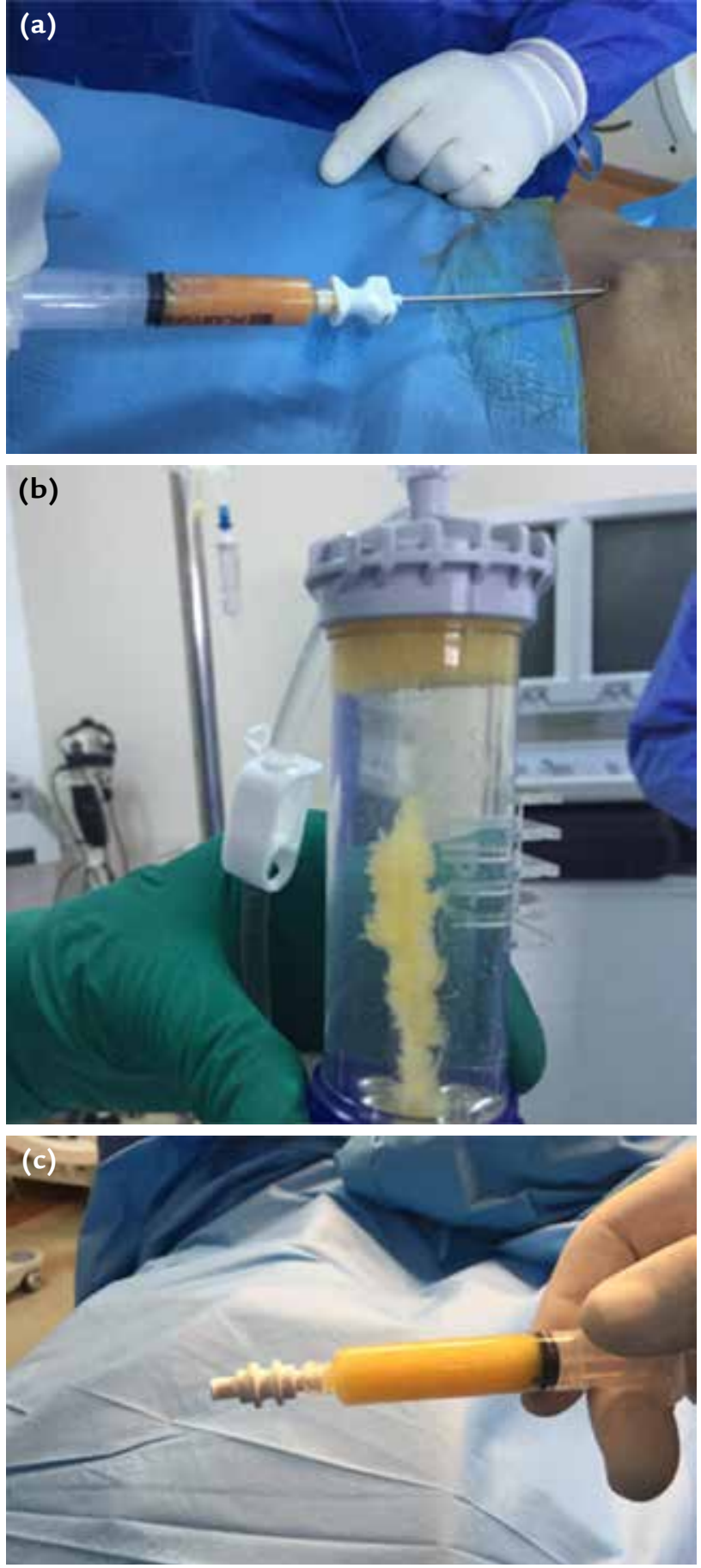

Şekil 3. a-c. Lipo aspirasyon (a); hücrelerin ayrıştırılması (b); elde edilen hücre konsantrasyonu (c).

Çok basit bir lokal anestezi ile liposuction yapılır ve 150-200 cc yağ alınır. Bu yağ, ameliyathanede çeşitli teknikler ile işlenir ve hücre konsantrasyonu elde edilir. Bazı yöntemlerde enzim kullanılmakta ve işlem süresi

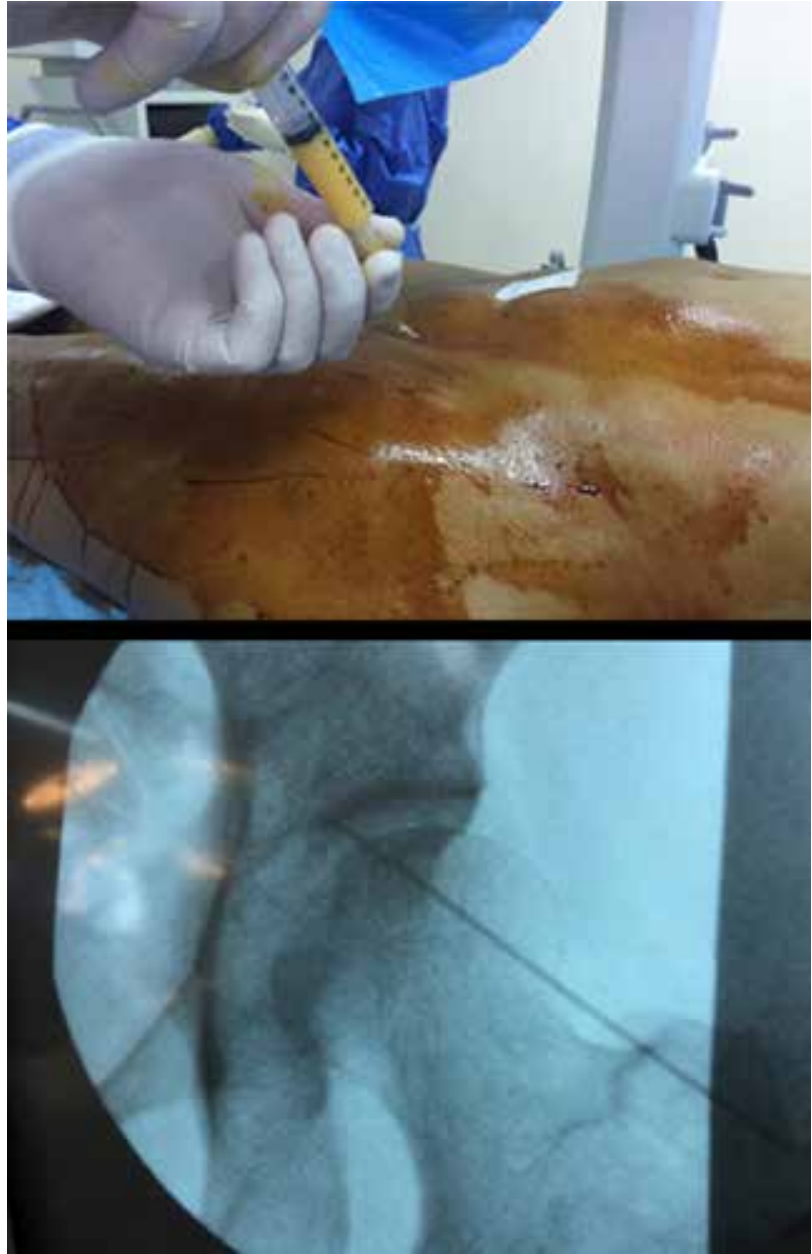

Şekil 4. Hücre konsantrasyonunun hastaya verilmesi.

iki saati bulmaktadır. Ancak, bazı tekniklerde enzim kullanılmamakta, mekanik kapalı filtrasyon sistemleri kullanılarak daha çabuk materyal elde edilmektedir (Şekil 3).

Elde edilen hücre konsantrasyonları, ameliyathanede aynı seansta enjeksiyon şeklinde hastanın eklemlerine uygulanır. Hasta aynı gün taburcu edilir ve herhangi bir kısıtlama uygulanmaz. Bu enjeksiyon yöntemi, dejeneratif kıkırdak lezyonlarında tercih edilmektedir (Şekil 4 ve 5).

Kulanım kolaylığı açısından, tek seanslı ve minimal invaziv yöntemler tercih edilmeye başlanacaktır.

Aynı şekilde, kemik iliğinden de kök hücre ihtiva eden süspansiyonlar elde edilerek eklem içine verilmektedir.

Son beş yılda çok fazla gelişmelerin yaşandığı kıkırdak lezyon tedavilerinde hücresel seviyedeki tekniklerin daha da artacağı görülmektedir. 


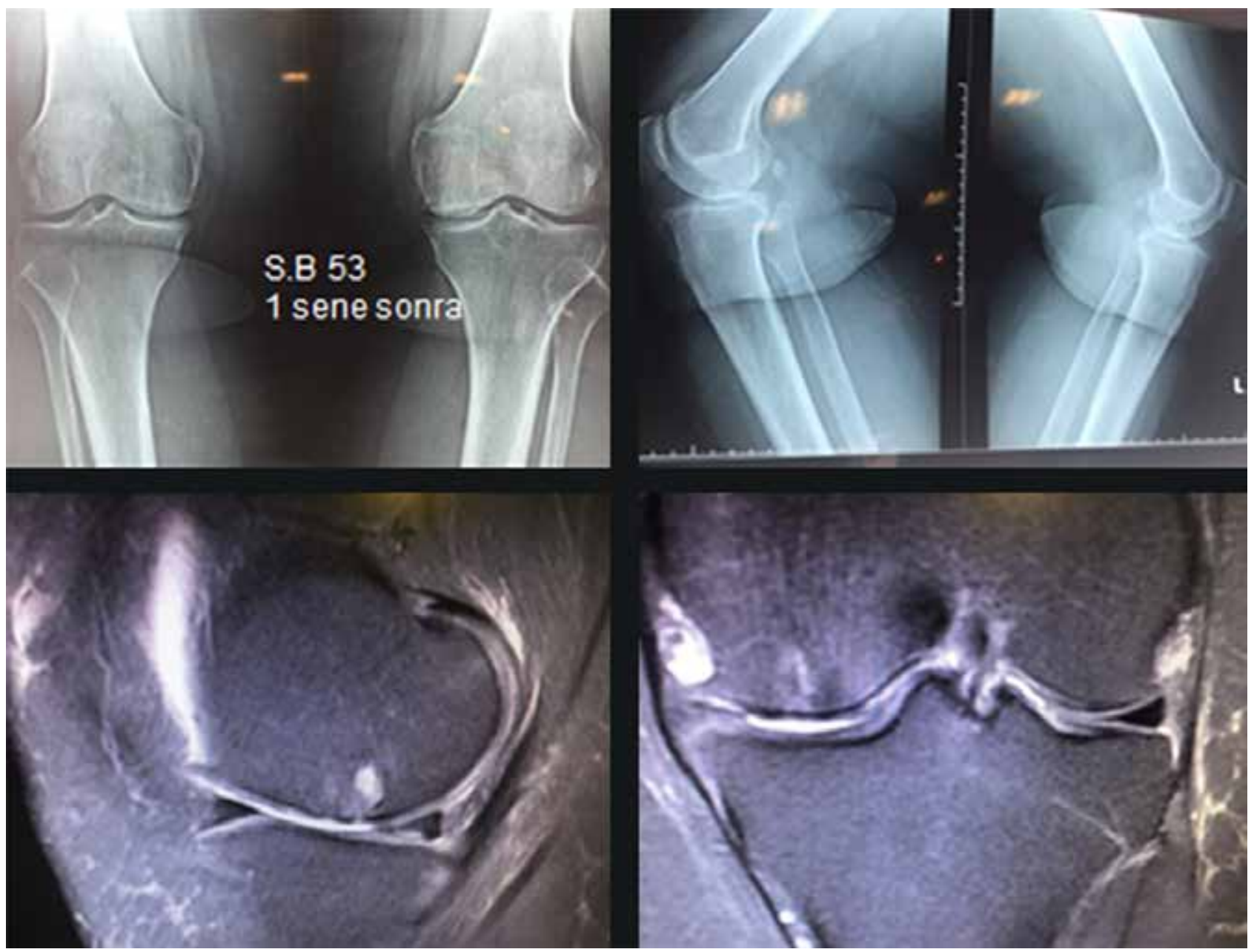

Şekil 5. Lipogems ${ }^{\circledast}$ hücre konsantrasyonu (bir yıl sonra).

\section{KAYNAKLAR}

1. De Coppi P, Bartsch G Jr, Siddiqui MM, Xu T, Santos CC, Perin L, Mostoslavsky G, Serre AC, Snyder EY, Yoo JJ, Furth $\mathrm{ME}$, Soker S, Atala A. Isolation of amniotic stem cell lines with potential for therapy. Nat Biotechnol 2007;25(1):1006. Crossref

2. Barcena A, Muench MO, Kapidzic M, Gormley M, Goldfien GA, Fisher SJ. Human placenta and chorion: potantial additional sources of hematopoetic stem cells for transplantation. Transfusion 2011;51 Suppl 4:94S-105S. Crossref

3. Smith AG. Embryo-derived stem cells of mice and men. Annu Rev Cell Dev Biol 2001;17:435-62. Crossref

4. Weissman IL, Anderson DJ, Gage F. Stem and progenitor cells: origins, phenotypes, lineage commitmens, and transdifferentiations. Annu Rev Cell Dev Biol 2001;17:387403. Crossref

5. Potten CS, Wilson JW. The development of epitelial stem cell concepts. In: Lanza R, editor. Essentials of Stem Cell Biology. San Diego, USA: Academic Press; 2009. p.17-27.
6. Caplan Al. Mesenchymal stem cells. J Orthop Res 1991;9(5):641-50. Crossref

7. Can A. Searching for in vivo traces of mesenchymal stem cells and their ancestors. In: Turksen K, editor. Adults and Embryonic Stem Cells. Humana Press; 2012. p.11-24. Crossref

8. Prockop DJ. Marrow stromal cells as stem cells for nonhematopoietic tissue. Science 1997;276(5309):71-4.

9. Huang JI, Kazmi N, Durbhakula MM, Hering TM, Yoo JU, Johnstone B. Chondrogenic potential of progenitor cells derived from human bone marrow and addipose tissue: a patient matched comparison. Ortoph Res 2005;23(6):1383-9. Crossref

10. Caplan Al. The mesengenic process. Clin Plast Surg 1994;21(3):429-35.

11. Banfi A, Muraglia A, Dozin B, Mastrogiacomo M, Cancedda R, Quarto R. Proliferation kinetics and differentiation potential of ex vivo expanded human bone marrow stromal cells: Implications for their use in cell therapy. Exp Hematol 2000;28(6):707-15. 
12. Balci D, Can A. The assessment of cryopreservation conditions for human umbilical cord stroma-derived mesenchymal stem cells towards a potential use for stem cell banking. Curr Stem Cell Res Ther 2013;8(1):60-72.

13. Caplan Al. Mesenchymal stem cells in regenerative medicine, Chapter 43. In: Atala A, Lanza R, editors. Handbook of Stem Cells, 2nd ed. San Diego: Academic Press; 2013. p.493-502.

14. Kim SM, Lim JY, Park SI, Jeong $\mathrm{CH}$, Oh JH, Jeong $\mathrm{M}$, Oh W, Park SH, Sung YC, Jeun SS. Gene therapy using TRAIL-secreting human umbilical cord blood-derived mesenchymal stem cells againts intracranial glioma. Cancer Res 2008;68(23):961423. Crossref

15. Kuhbier JW, Weyand B, Radtke C, Vogt PM, Kasper C, Rimers $\mathrm{K}$. Isolation, characterization, differentiation, and application of adipose-derived stem cells. Adv Biochem Eng Biotechnol 2010;123:55-105. Crossref

16. Koga $H$, Engebretsen L, Brinchman JE, Muneta T, Sekiya I. Mesenchymal stem cell-based therapy for cartilage repair: a review. Knee Surg Sports Traumatol Arthrosc 2009;17(11):1289-97. Crossref

17. Johnstone B, Hering TM, Caplan Al, Goldberg VM, Yoo JU. In vitro chondrogenesis of bone marrow-derived mesenchymal progenitor cells. Exp Cell Res 1998;238(1):265-72. Crossref

18. An C, Cheng Y, Yuan Q, Li J. IGF-1, BMP-2 induced differentiation of adipose-derived mesenchymal stem cells into chondrocytes-like cells. Ann Biomed Eng 2010;38(4):164754. Crossref

19. Jingushi S, Heydemann A, Kana SK, Macey LR, Bolander ME. Acidic fibroblast growth factor (aFGF) injection stimulates cartilage enlargement and inhibits cartilage gene expression in rate fracture healing. J Orthop Res 1990;8(3):364-71. Crossref

20. Janzen V, Forkert R, Flemig HE, SaitoY, Waring MT, Dombkovski DM, Cheng T, DePinho RA, Sharpless NE, Scadden DT. Stem cell ageing modified bu the cyclin-dependent kinase inhibitor p16NK4a. Nature 2006;443(7110):421-4. Crossref

21. Tarte K, Gaillard J, Lataillade IJ, Fouillard L, Becker M, Mossafa $\mathrm{H}$, Tchirkov A, Rouard H, Henry C, Splingard M, Dulong J, Monnier D, Gourmelon P, Gorin NC, Sensebé L; Société Française de Greffe de Moelle et Thérapie Cellulaire. Clinical-grade production of human mesenchymal stromal cells: occurence of aneuploidy without transformation. Blood 2010;115(8):1549-53. Crossref

22. Ortiz LA, Gambelli F, McBride C, Gaupp D, Baddoo M, Kaminkski N, Phinney DG. Mesenchymal stem cell engraftment in lung is enhanced in response to bleomycin exposure and ameliorates its fibrotic effects. Proc Natl Acad Sci U S A 2003;100(14):8407-11. Crossref

23. Fang B, Shi M, Liao L, Yang S, Liu Y, Zhao RC. Systemic infusion of FLK1(+) mesenchymal stem cells ameliorate carbon tetrachloride-induced liver fibrosis in mice. Transplantation 2004;78(1):83-8.

24. Ruster B, Gotting S, Ludwing RJ, Bistrian R, Müller S, Seifried E, Gille J, Henschler R. Mesenchymal stem cells display coordinated rolling and adhesion behavior on endothelial cells. Blood 2006;108(12):3938-44. Crossref

25. Scmidt A, Ladage D, Steingen C, Brixius K, Schinköthe T, Klinz FJ, Schwinger RH, Mehlhorn U, Bloch W. Mesenchymal stem cells transmigrate over the endothelial barrier. Eur J Cell Biol 2006;85(11):1179-88. Crossref

26. Noel D, Djouad F, Bouffi C, Mrugala D, Jorgensen C. Multipotent mesenchymal stromal cells and immunu tolerance. Leuk Lymphoma 2007;48(7):1283-9. Crossref
27. Majumdar MK, Keane-Moore M, Buyoner D, Hardy WB, Moorman MA, Mclntosh KR, Mosca JD. Characterization and functionality of cell surface molecules on human mesenchymal stem cells. J Biomed Sci 2008;10(2):228-41.

28. Götherström $C$, Ringdén $O$, Tammik C, Zetterberg $E$, Westgren $M$, Le Blanc K. Immunologic properties of human fetal mesenchymal stem cells. Am J Obstet Gnecol 2004;190(1):239-45. Crossref

29. Beyrh S, Borovsky Z, Mevorach D, Liebergall M, Gazit Z, Aslan $H$, Galun H, Rachmilewitz J. Human mesechymal stem cells alter antigen -presenting cell maturation and induce T-cell unrenponsiveness. Blood 2005;105(5):2214-9. Crossref

30. Buckwalter JA, Mankin HJ. Articular cartilage repair and transplantation. Arthritis Rheum 1998:41(8):1331-42. Crossref

31. Mankin HJ. The reaction of articular cartilage to injury and oateoarthritis (second of two parts). $N$ Engl J Med 1974:291(25):1335-40. Crossref

32. Dell'Accio F, Vanlauwe J, Bellemans J, Neys J, de Bari C, Luyten FP. Expanded phenotypically stable chondrocytes persist in the repair tissue and contribute to cartilage matrix formation and structural integration in a goat model of autologous chondrocyte implantation. J Orthop Res 2003;21(1):123-31. Crossref

33. Hunziker EB. Articular cartilage repair: basic science and clinical progress. A review of the current status and prospects. Osteoarthritis Cartilage 2002;10(6):432-63. Crossref

34. Caplan Al, Dennis JE. Mesenchymal stem cellsas trophic mediators. J Cell Biochem 2006;98(5):1076-184. doi: $10.1002 / j c b .20886$

35. Ganz R, Gill TJ, Gautier E, Ganz K, Krügel N, Berlemann U. Surgical dislocation of the adult hip a tecnique with full access to the femoral head and acetabulum without the risk of avascular necrosis. J Bone Joint Surg Br 2001;83(8):1119-24.

36. Alford JW, Cole BJ. Cartilage restoration, part 2: techniques, outcomes, and future directions. Am J Sports Med 2005;33(3):443-60. Crossref

37. Barlett W, Skinner JA, Gooding JR, Carrington RW, Flanagan AM, Briggs TW, Bentley G. Autologous chondrocyte implantation versus matrix-induced autologous chondrocyte implantation for ostechondral defects of the knee: a prospective, randomized study. J Bone Joint Surg $\mathrm{Br}$ 2005;87(5):640-5. Crossref

38. Kitaoka HB, Alexander IJ, Adelaar RS, Nunley JA, Myerson MS, Sanders M. Clinical rating systems fot the anklehindfoot, midfoot, hallux and lesser toes. Foot Ankle Int 1994;15(7):349-54. Crossref

39. Nehrer S, Breinan HA, Ramappa A, Hsu HP, Minas T, Shortkroff S, Sledge CB, Yannas IV, Spector M. Chondrocyteseeded collagen matrices implanted in a chondral defect in a canine model. Biomaterials 1998;19(24):2313-28.

40. Kreuz PC, Steinwachs MR, Erggelet C, Krause SI, Konrad G, Uhi M, Südkamp N. Results after microfractures of fullthickness chondral defect in different compartments in the knee. Osteoarthritis Cartilage 2006;14(11):1119-25. Crossref

41. Chung CB, Frank LR, Resnick D. Cartilage imaging tecniques: current clinical applications and state of the art imaging. Clin Orthop Relat Res 2001;(391 Suppl):S370-8.

42. Behrems P, Bitter T, Kurz B, Russlies M. Matrix associated autologous chondrocyte transplantation/implantation (MACT/MACI): 5-year follow up. Knee 2006;13(3):194-202. Crossref 
43. Khan WS, Johnson DS, Hardingham TH. The potential of stem cells in the treatment of knee cartilage defects. Knee 2010;17(6):368-74. Crossref

44. Chen FH, Tuan RS. Mesenchymal stem cells in arthritic diseases. Arthritis Res Ther 2008;10(5):223. Crossref

45. Davatchi F, Abdollahi BS, Mohyeddin M, Shahram F, Nikbin B. Mesenchymal stem cell therapy for knee osteoarthritis. Preliminary report of four patients. Int J Rheum Dis 2011;14(2):211-5. Crossref
46. Emadedin M, Aghdami N, Taghiyar L, Fazeli R, Moghadasali R, Jahangir S, Farjad R, Baghaban Eslaminejad M. Intraarticular injection of autologous mesenchymal stem cells in six patients with knee osteoarthritis. Arch Iran Med 2012;15(7):422-8. Crossref

47. Kuroda R, Ishida K, Matsumoto $T$, Akisue $T$, Fujioka $H$, Mizuno K, Ohgushi H, Wakitani S, Kurosaka M. Treatment of a full-thickness articular cartilage defect in a femoral condyle of an athlete with autologous bone-marrow stromal cells. Osteoarthritis Cartilage 2007;15(2):226-2. Crossref 